$11-2015$

\title{
Shylock Celebrates Easter
}

Brooke Conti

Cleveland State University, b.conti@csuohio.edu

Follow this and additional works at: https://engagedscholarship.csuohio.edu/cleng_facpub

Part of the Literature in English, British Isles Commons

How does access to this work benefit you? Let us know!

Publisher's Statement

This article first appeared in Modern Philology, Volume 113, Issue 2, 2015.

\section{Recommended Citation}

Conti, Brooke, "Shylock Celebrates Easter" (2015). English Faculty Publications. 80.

https://engagedscholarship.csuohio.edu/cleng_facpub/80

This Article is brought to you for free and open access by the English Department at EngagedScholarship@CSU. It has been accepted for inclusion in English Faculty Publications by an authorized administrator of EngagedScholarship@CSU. For more information, please contact library.es@csuohio.edu. 


\title{
Shylock Celebrates Easter
}

\author{
B ROOKE CONTI \\ Cleveland State University
}

The final act of The Merchant of Venice (ca. 1596-97) has always struck some readers as superfluous. By the end of act 4 the pound-of-flesh plot is resolved and even the love plots have few loose ends left to tie up. Yet Shakespeare gives us another whole act, a leisurely, playful return to Belmont and to the very minor problems of a half-dozen generally happy lovers. But if act 5 feels unnecessary to many readers, it poses a special problem for those who regard Shylock as the play's dramatic and emotional heart. If Shylock is, in whatever sense, the work's hero-and especially if he is intended as a witness to Venetian intolerance and Christian hypocrisy-then how do we account for the insistent festivity of act 5 ? For the play does not merely leave Shylock behind; it briskly strips him of both identity and possessions before turning to the moonlit gambols of those responsible for his undoing.

One common response to the seemingly radical tonal shift between acts 4 and 5 has been to scour the latter for signs of dissension and unease: evidence that all is not as well in Belmont as it appears. ${ }^{1}$ But although there

This essay benefited from the advice of numerous people. Those who helped point me in the right direction in my liturgical research include Susan D. Amussen, Daniel Gibbons, Robert J. Kennedy, Gordon W. Lathrop, Judith Maltby, Derek Olsen, Carin Ruff, Frank C. Senn, Debora Shuger, William S. Stafford, and John N. Wall. Two different seminars at the Shakespeare Association of America's annual conference, run by Lori Humphrey Newcomb and Cora Fox, and Jonathan Baldo and Isabel Karremann, respectively, allowed me to try out earlier versions of these arguments; I am grateful to the organizers and all the participants for their feedback. James J. Marino read innumerable drafts along the way, and at a late stage both Richard Preiss and Modern Philology's two readers made a number of detailed interventions. This essay could not have reached its final form without their generous engagement with my work.

1. See, e.g., Mary Janell Metzger, "Now by My Hood, A Gentle and No Jew': Jessica, The Merchant of Venice, and the Discourse of Early Modern English Identity," PMLA 113 (1998): 59-60; Marc Berley, "Jessica's Belmont Blues: Music and Merriment in The Merchant of Venice," in Opening the Borders: Inclusivity in Early Modern Studies; Essays in Honor of James V. Mirollo, ed. Peter C. Herman (Newark: University of Delaware Press, 1999), 185-205; Lisa Lampert, Gender and Jewish Difference from Paul to Shakespeare (Philadelphia: University of Pennsylvania Press, 2005),

(C) 2015 by The University of Chicago. All rights reserved. 0026-8232/2015/11302-0002 $\$ 10.00$ 
may be modest hints of possible future marital trouble for one or more of the play's romantic couples, similarly modest hints hover over all the couples in all of Shakespeare's comedies. Even the happiest of Shakespeare's comedic conclusions are shadowed by reminders of the young lovers' rashness, naïveté, or lack of sufficient insight into self or partner, and the fifth act of Merchant of Venice is no more ominous in this regard than the fifth acts of Midsummer Night's Dream (ca. 1594-96), Much Ado About Nothing (ca. 1598), or Twelfth Night (ca. 1601). In Merchant of Venice, as in those other plays, the audience is encouraged to suspend their misgivings and give themselves over to the festivities. ${ }^{2}$ As the six lovers work out the terms of their relationships with music, moonlight, and practical jokes, the play seems to have discarded Shylock as easily as the Venetians have.

However, while act 5's lightheartedness may disquiet or even repel modern audiences, it does not represent a radical shift away from the concerns of act 4 . As I shall argue, the two acts are united by a pervasive Easter symbolism that revolves around Shylock's conversion. Act 4's echoes of the passion and crucifixion are well known. ${ }^{3}$ But if act 4 alludes to Good Friday, act 5 alludes to Holy Saturday and the dawning of Easter Sunday. Beginning with the love duet between Jessica and Lorenzo and continuing through the end of the play, Shakespeare repeatedly evokes the ancient Easter Vigil service, the heart of which involved the reception of new converts into the church. This extended liturgical allusion suggests the play's continuing preoccupa-

165-67; Janet Adelman, Blood Relations: Christian and Jew in "The Merchant of Venice" (University of Chicago Press, 2008), 76-77; Aaron Kitch, "Shylock's Sacred Nation," Shakespeare Quarterly 59 (2008): 154-55; Harry Berger Jr., "Mercifixion in the Merchant of Venice: The Riches of Embarrassment," Renaissance Quarterly, n.s., 38 (2010): 20-23. See also Kenneth Gross, who describes Belmont as "dangerous and vaguely tacky" and "haunted by a vague awareness of the sacrifices or shames" on which its pleasures depend (Shylock Is Shakespeare [University of Chicago Press, 2006], 30-31). Of course, there is a long tradition of reading act 5 as a wholly harmonious conclusion to the play, but such readings generally draw no meaningful connection between the satisfying closure of the play's love and friendship plots and Shylock's conversion in the previous act; in such readings Shylock is no more or less important to the play in which he appears than Malvolio is to his. See, e.g., C. L. Barber, Shakespeare's Festive Comedy (Princeton University Press, 1959), 187; Lawrence Danson, The Harmonies of "The Merchant of Venice" (New Haven, CT: Yale University Press, 1978), 170-95.

2. The conclusion of Midsummer Night's Dream seems an especially relevant analogue. The bed blessing (another pre-Reformation practice) functions, in itself, as a satisfying and celebratory conclusion. But as the fairies bless the future issue of Theseus and Hippolyta's bed, those audience members who catch the allusion will realize that, as happy as the couple may now be, a much darker future lies ahead.

3. For a summary of these allusions, see Barbara K. Lewalski, "Biblical Allusion and Allegory in The Merchant of Venice," Shakespeare Quarterly 13 (1962): 339. Marjorie Garber notes that the network of sacrificial allusions in act 4 has led in recent years to a stage tradition in which Antonio is often bound in a cruciform position. See Garber, Shakespeare After All (New York: Pantheon, 2004), 301. 
tion with Shylock; at the same time, the liturgy's vexed status in Protestant England raises questions about religious change that go beyond the play's Jewish characters.

That this allusion has been ignored in Shakespeare criticism is not surprising. Although the Easter Vigil dates back to the earliest days of Christianity, it appears to have vanished from English worship at the Reformation (not to return to it until the twentieth century). ${ }^{4}$ The few scholars who have noticed the allusion have therefore assumed that the service would have been unknown to any but devoted Catholics and, based on this assumption, adduced the allusion to their case for a "Catholic Shakespeare. ${ }^{.5}$ However, a careful investigation of the liturgy's history shows many beliefs about its place in post-Reformation Europe to be mistaken. As I will demonstrate, the printed record reveals that the Easter Vigil had a long half-life in the Protestant imagination. Well into the seventeenth century, English writers were still talking about the liturgy and quoting from its most important literary component, the hymn known as the Exultet. There are many reasons that the Easter Vigil remained familiar, but its chief interest for Protestants seems to have been its place in the early church. Amply described in the writings of the Fathers, the Saturday night service was the first Easter service celebrated by Christians and was for centuries the only Easter service. From

4. For the early history of the Easter Vigil service, see Thomas M. Finn, "It Happened One Saturday Night: Ritual and Conversion in Augustine's North Africa," Journal of the American Academy of Religion 58 (1990): 589-616; Thomas Forrest Kelly, The Exultet in Southern Italy (Oxford University Press, 1996), 31-43; John Walton Tyrer, Historical Survey of Holy Week: Its Services and Ceremonials (Oxford University Press, 1932), 147-74; Josef A. Jungmann, The Early Liturgy: To the Time of Gregory the Great (University of Notre Dame Press, 1959), 262-64. The medieval history of the liturgy is summarized by Frank C. Senn in The People's Work: A Social History of the Liturgy (Minneapolis: Fortress, 2006), 162-65. A movement to restore the Easter Vigil to churches in the Anglican Communion began in the late nineteenth century, and the liturgy could be found in a few places in both England and the United States throughout the twentieth century. However, it was not until the late 1970s — with the approval of the 1979 Book of Common Prayer - that the form of the liturgy became standardized and its observance widespread. My thanks to John N. Wall for this summary of the recent history of the vigil. See also James W. Farwell, This Is the Night: Suffering, Salvation, and the Liturgies of Holy Week (New York: Clark, 2005), 43-44.

5. Mark L. Gnerro noted the presence of this allusion in a short essay, "Easter Liturgy and the Love Duet in MV 5.1," American Notes and Queries 18 (1979): 19-21. However, Gnerro does not pursue the full extent of this allusion, and the few scholars who have either cited him or noted the allusion on their own tend to be using it in the service of more or less tendentious arguments about Shakespeare's alleged Catholic sympathies. See Marjorie Wynn-Davies, "Rubbing at Whitewash: Intolerance in The Merchant of Venice," in A Companion to Shakespeare's Works: The Comedies, ed. Richard Dutton and Jean E. Howard (Oxford: Blackwell, 2005), 366; Clare Asquith, Shadowplay: The Hidden Beliefs and Coded Politics of William Shakespeare (New York: Public Affairs, 2005), 119-21; Dennis Teti, "The Unbloody Sacrifice: The Catholic Theology of Shakespeare's Merchant of Venice," Interpretation: A Journal of Political Philosophy 33 (2006): 45-91. 
its opening hymn to its scripture readings, the liturgy involved a sustained narration of Christianity's origins in Judaism; it was also, in the ancient church, the only time of year at which converts were baptized.

I will say more about both the service and its place in Protestant thought later, but some of the liturgy's relevance to Merchant should already be apparent. The fact that Shakespeare added Shylock's conversion to the material he took from his source narratives suggests its importance to the play, ${ }^{6}$ but scholars have long been divided over how to read this conversion-or the conversion of Shylock's daughter Jessica. One line of interpretation, advanced most compellingly by Barbara Lewalski, sees Merchant as a largely untroubled articulation of Christian supersessionist theology-a work that celebrates the replacement of the Old Law with the New. ${ }^{7}$ Readings in this vein usually do not linger over the conversions of the play's two Jews, regarding them as merely symbolic of the general conversion of the Jews that Christians expected to usher in the apocalypse. But whereas this interpretation suggests that the play sees its Jewish characters primarily as types and abstractions, most readers in the decades since James Shapiro's Shakespeare and the Jews have been profoundly interested in the question of conversion and the way Shakespeare's characters might reflect or occlude the experiences of real European Jews. ${ }^{8}$ A great deal of research has helped to illuminate the ways Shakespeare's play engages with early modern understandings of Jewishness as both religion and race; in particular, the fraught nature of Jewish identity and Christian skepticism about whether a Jew truly could "turn gentle" have led a variety of scholars to see Merchant as an unstable work, one that may wish to celebrate the replacement of the letter of law with the law of love but is unable to do so. ${ }^{9}$ Incapable of fully assimilating its Jewish characters or reducing flesh-and-blood Jews to convenient types, the play-scholars such as Janet Adelman and Kenneth Gross argue-tilts toward tragedy. In this reading, conversion is where the conflict between the ostensibly happy ending of the play and the problem of the Jews is most evident.

The echoes of the Easter Vigil in act 5 extend and complicate both of these readings. On the one hand, the liturgy articulates an unambiguously

6. In Il pecorone, as in other similar pound-of-flesh stories, the Shylock figure merely tears up the bond and departs in a fury.

7. Lewalski, "Biblical Allusion," 327-43. See also John S. Coolidge, "Love and Law in The Merchant of Venice," Shakespeare Quarterly 27 (1976): 243-63; and Danson, Harmonies, 55-81.

8. James Shapiro, Shakespeare and the Jews (New York: Columbia University Press, 1996).

9. A partial list of the works that consider Merchant in terms of early modern conceptions of Jewish identity would include Adelman, Blood Relations; Lampert, Gender and Jewish Difference; Metzger, "Now by My Hood"; Kitch, "Sacred Nation"; and M. Lindsay Kaplan, "Jessica's Mother: Medieval Constructions of Jewish Race and Gender in The Merchant of Venice," Shakespeare Quarterly 58 (2007): 1-30. 
supersessionist vision of the relationship between Jew and Christian, and act 5's festive setting encourages a celebratory attitude toward both conversions. On the other hand, the liturgy's deep engagement with the Hebrew Bible, and its association with the moment when Judaism became Christianity, support Adelman's argument that Merchant "persistently troubles the distinction between Christian and Jew." ${ }^{10}$ But while act 5's allusions to the Easter Vigil foreground some of the same problems of succession and substitution that interest Adelman, they also remind us that Christianity's identity crisis, in the late sixteenth century, is only partly about its debts to Judaism. A service tied to the ancient church but familiar from the pre-Reformation one, the Easter Vigil mediates between Jew and Christian, Protestant and Catholic. We cannot know precisely what Shakespeare intended in alluding to the liturgy, and we cannot know how any one of his audience members would have responded (assuming such a person recognized the allusions at all). Yet the play's evocation of this service, once thought to have vanished at the Reformation, suggests both a desire to look past denominational divides and the difficulty of doing so. In the end, the play's generosity may be limited by the theological presumptions and ethnic prejudices of its age, but the Easter Vigil's liminal status and surfeit of possible meanings allow for the coexistence of both a more celebratory and a more skeptical reading of interfaith relations.

\section{OUR PASSOVER FEAST}

Even those who have not noticed the Easter symbolism in act 5 have often thought that, in opening with Jessica, the play's final scene serves as a commentary on her father's fate. In recent years, critics have tended to focus on the relatively slight evidence for discord between Jessica and Lorenzo-taking it as a sign that Jessica's assimilation as a Venetian Christian will be no smoother than they presume Shylock's could be. ${ }^{11}$ However, act 5's allusions to the Easter Vigil seem to pull in the opposite direction, suggesting the success of Jessica's conversion and quite possibly Shylock's as well. In order to make that case as clearly as possible, for the next several pages I will be taking the play's use of the liturgy relatively "straight," by which I mean laying out the allusion's implications for the play as a theologically orthodox late sixteenth-century Christian might have read them. In the second

10. Adelman, Blood Relations, 4. See also David Nirenberg, "Shakespeare's Jewish Questions," Renaissance Drama, n.s., 38 (2010): 77-113.

11. See, e.g., Adelman, Blood Relations, 66-98; Lampert, Gender and Jewish Difference, 160-67; Shapiro, Shakespeare and the Jews, 131-65; Metzger, "Now by My Hood," 52-63. M. Lindsay Kaplan is among those who see a smoother path to assimilation for Jessica than for her fatherbased on her gender and her marriage into the gentry. See Kaplan, "Jessica's Mother." 
part of this essay, I will discuss the ways the liturgy's history might have complicated or challenged such a reading.

As the scene begins, Jessica and Lorenzo are inscribing their love story within a larger romantic narrative, seeking precedents in famous lovers past. Much has been written about the classical precedents they come up with and especially the ominous endings that those lovers meet. But if the local allusions in this duet have been carefully scrutinized, the larger and more structural one has not been. In fact, Jessica and Lorenzo's narrative of repetition and continuity alludes to a far grander one involving the whole of providential history. The lovers' repeated refrain "on such a night" echoes the formula "this is the night" (haec nox est) from the Exultet, the hymn that opens the Easter Vigil liturgy. This allusion shows that the play has not left act 4 or Shylock behind, for the relationship between Jew and Christian remains very much on its mind. Here is the relevant portion of the hymn:

This is our Passover feast,

When Christ, the true Lamb, is slain,

Whose blood consecrates the homes of all believers.

This is the night

When first you saved our fathers:

You freed the people of Israel from their slavery

And led them dry-shod through the sea.

This is the night

When the pillar of fire destroyed the darkness of sin!

This is the night

When Christians everywhere,

Washed clean of sin and freed from all defilement,

Are restored to grace and grow together in holiness.

This is the night

When Jesus Christ broke the chains of death

And rose triumphant from the grave.

What good would life have been to us,

Had Christ not come as our Redeemer?

Father, how wonderful your care for us!

How boundless your merciful love!

To ransom a slave you gave away your Son.

O happy fault,

O necessary sin of Adam,

Which gained for us so great a Redeemer! 
Most blessed of all nights

Chosen by God to see Christ rising from the dead! ${ }^{12}$

As one of the earliest articulations of the theological principle of the "fortunate fall" or "felix culpa," the Exultet reads Adam and Eve's transgression and all the subsequent events of the Hebrew Bible as necessary preludes to Christ's Incarnation and sacrifice; it therefore gives voice to the kind of supersessionist theology that scholars have long understood Shakespeare's play to be wrestling with.

For the most part, Merchant's echoes of the Exultet seem to endorse the liturgy's own understanding of Jewish-Christian succession, though as always in Shakespeare there is room for doubt. Just as Jessica and Lorenzo conflate the story of their love with tales of lovers in times past, so does the Exultet conflate God's deliverance of the Jews with Christ's salvation of Christians. Moreover, the allusion suggests that we might read Jessica and Shylock's conversion as the latest event in this providential scheme. ${ }^{13}$ Although it is possible that the pessimistic classical allusions in the love duet override or ironize the more hopeful Christian ones, the tension between the two sets

12. This and all subsequent quotations from the Exultet are taken from the English translation in the 1970 Roman Missal. I have preferred this translation for two reasons: the version of the Exultet in the Roman Missal is longer than that in the Book of Common Prayer, and the 1970 translation is rendered in smoother and more idiomatic English than the new translation of 2011. These lines come from the middle of the hymn, approximately lines 30-55 (all line numbers are my own). The Latin is as follows:

Haec sunt enim festa paschalia, in quibus verus ille agnus occiditur, cuius sanguine postes fidelium consecrantur. Haec nox est, in qua primum patres nostros, filios Israel eductos de Aegypto, Mare Rubrum sicco vestigio transire fecisti. Haec igitur nox est, quae peccatorum tenebras columnae illuminatione purgavit. Haec nox est, quae hodie per universum mundum in Christo credentes, a vitiis saeculi et caligine peccatorum segregatos, reddit gratiae, sociat sanctitati. Haec nox est, in qua, destructis vinculis mortis, Christus ab inferis victor ascendit. Nihil enim nobis nasci profuit, nisi redimi profuisset. $\mathrm{O}$ mira circa nos tuae pietatis dignatio. $\mathrm{O}$ inaestimabilis dilectio caritatis: ut servum redimeres, filium tradidisti. O certe necesserium Adae peccatum, quod Christi morte deletum est. $\mathrm{O}$ felix culpa, quae talem ac tantum meruit habere redemptorem. $\mathrm{O}$ vere beata nox, quae sola meruit scire tempus et horam, in qua Christus ab inferis resurrexit.

The Latin text (here and elsewhere) is taken from Manlio Sodi and Achille Maria Triacca, eds., Missale Romanum: Editio princeps (Vatican City: Libreria Editrice Vaticana, 1998), 258-60. (All contractions and other manuscript notations have been expanded.) For the full text of the Easter Vigil service in something close to the form that Shakespeare most likely knew, see either Sodi and Triacca, Missale Romanum, 253-92; or J. Wickham Legg, ed., The Sarum Missal: Edited from Three Early Manuscripts (Oxford: Clarendon, 1916), 115-34.

13. Most Christians regarded the conversion of the Jews as a necessary forerunner to the second coming and the end of historical time. For more on the apocalyptic significance of Jessica and Shylock's conversions, see Lewalski, "Biblical Allegory," 334, 341; Shapiro, Shakespeare and the Jews, 133-34; Julia Reinhard Lupton, Citizen-Saints: Shakespeare and Political Theology (University of Chicago Press, 2005), 85-86. 
of allusions need not be resolved that way. The fact that Jessica and Lorenzo add their names to a list of lovers whose stories came to bad ends may be simply irrelevant (to the play, if not to them), for in the grand scheme of salvation, romantic love is not particularly important. Another possibility is that Jessica and Lorenzo's relationship should be read typologically-as the happy fulfillment of those earlier, equally passionate, but less successful preChristian romances. Typology is repetition with a difference.

Shakespeare's interest in the Easter Vigil is not confined to the language of the Exultet but encompasses many of the service's most significant features. As the hymn implies, the vigil was originally modeled by early Christians on the Passover seder, and even in its later forms remained peculiarly focused on Israel and its redemption. ${ }^{14}$ Traditionally, the service began around midnight and ended at dawn. The congregation assembled in darkness, symbolizing the end of the light of the Old Law. New fire was sparked and blessed, symbolizing the light of Christ, and from this flame the paschal candle was lit. Usually a procession formed behind the candle as the deacon recited the Exultet; during the recitation, the other candles in the church were lit, one by one, from the paschal candle, until the entire congregation was illuminated. The liturgy then proceeded to readings from scripture, all taken from the Hebrew Bible, including some of the same episodes from the patriarchal narratives that Shakespeare recalls elsewhere in the play. ${ }^{15}$ However, the center and the highlight of the service in the ancient church was the reception of converts via baptism followed by Holy Communion. After the celebration of the Eucharist, the liturgy concluded at first light. ${ }^{16}$

Act 5 of Merchant might be said to loosely follow the progress of the liturgy. In addition to opening with the language of the Exultet, the scene moves from darkness to dawn, as the characters repeatedly remind the audience. At the beginning of the act "the moon shines bright" upon Jessica and Lorenzo (5.1.1), and when Portia and Nerissa arrive it is still dark enough that they can see a candle shining far off in her house; they remark on the power of this single candle, the only source of artificial light mentioned in the scene. ${ }^{17}$ In Portia's words, it shines like "a good deed in a

14. See esp. Thomas J. Talley, The Origins of the Liturgical Year (New York: Pueblo, 1991), 5$7,49-50$.

15. The scene between Launcelot Gobbo and his father (2.2.26-90) is, of course, a parodic reenactment of Jacob's deception of his father, Isaac; Shylock narrates a later portion of the Jacob cycle in his first interview with Bassanio and Antonio (1.3.67-86); and portions of the trial scene also seem intended to evoke Abraham's binding of Isaac (4.1.1ff.).

16. See Tyrer, Historical Survey, 147-69.

17. All quotations and line numbers refer to the text of the play in The Norton Shakespeare: Based on the Oxford Edition, ed. Stephen Greenblatt, Walter Cohen, Jean E. Howard, and Katharine Eisaman Moss, 2nd ed. (New York: Norton, 2008). 
naughty world" (5.1.90). Upon Bassanio's return, however, Portia notes that the night sky has grown paler, like "the daylight sick," and at the end of the scene both she and Graziano comment, separately, that it is almost morning (5.1.123-25, 294, 302). These detailed references to the scene's nocturnal setting and its progress toward daylight strengthen the link with the Easter Vigil liturgy, and reading this scene alongside the Exultet provides additional insights into the play's conclusion. According to the Exultet, Easter Eve is a night of miraculous renewal and transformation:

Of this night scripture says:

"The night will be as clear as day:

it will become my light, my joy." 18

The power of this holy night dispels all evil, washes guilt away, restores lost innocence, brings mourners joy; it casts out hatred, brings us peace, and humbles earthly pride.

Night truly blessed when heaven is wedded to earth and man is reconciled with God!

(Lines 55-64) ${ }^{19}$

As several critics have argued, the Belmont of act 5 seems like something more than the usual Shakespearean green world; the play presents it as a heavenly sanctuary of peace and reconciliation. ${ }^{20}$ If we take act 5 's evocation of the Exultet seriously, however, it is not that Belmont, as a place, is necessarily so very heavenly-but that this specific night has hallowed it, enabling the reunions and reconciliations that conclude the play.

The Exultet's status as a piece of divine music also has consequences for act 5. The scene offers several examples of music's power to order, reconcile, and harmonize, beginning with the lovers' duet and continuing with Lorenzo's call for Portia's musicians to "bring [their] music forth into the air" (5.1.52). As he and Jessica wait for the musicians to appear, he points to the stars and explains that the music of the spheres is inaudible while humans are clad in their "muddy vesture of decay" (5.1.62-63). Presumably, this is why he calls for the musicians-to provide an audible substitute

18. The allusion here is to Psalm 138, a praise of God's omniscience and omnipotence.

19. "Haec nox est, de qua scriptum est: et nox sicut dies illuminabitur: et nox illuminatio mea in deliciis meis. Huius igitur sanctificatio noctis fugat scelera, culpas lavat: et reddit innocentiam lapsis et maestis laetitiam. Fugat odia, concordiam parat, curvat imperia.... O vere beata nox ... in qua terrenis caelestia, humanis divina iunguntur."

20. See, e.g., Lewalski, "Allusion and Allegory," 343; Coolidge, "Love and Law," 261-63. 
for the inaudible music of the spheres-but Lorenzo's investment in heavenly harmony also has a specific Easter resonance. Each of the stars, Lorenzo claims, sings "like an angel ... / Still choiring to the young-eyed cherubim" (5.1.60-61), words that evoke the opening lines of the Exultet. As the hymn's Latin title suggests, these lines direct the created world, including the denizens of heaven, to jubilation:

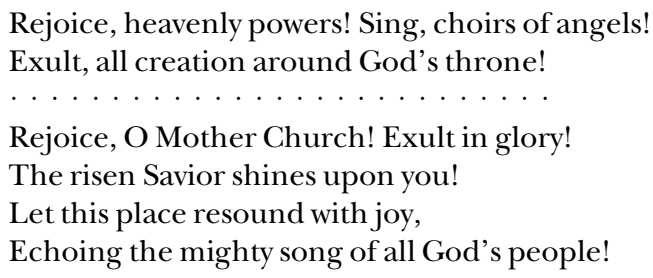

$$
\left(\text { Lines 1-12) }{ }^{21}\right.
$$

There is continuity, then, between music on earth, music in heaven, and a larger cosmic order.

Despite the many exclamation marks in the 1970 Roman Missal's English translation of the above passage, the Exultet's plainsong chant is solemn and meditative, more in keeping with Jessica's subsequent remark that she is "never merry" when she hears "sweet music" (5.1.68). Some readers have read Jessica's statement as a form of resistance to Lorenzo's musical enthusiasm-a sign that she is refusing to enjoy the music-and then interpreted Lorenzo's lengthy response as a pedantic and disapproving critique that links Jessica's lack of merriment with her father, whose dislike of music and festivity is noted several times in the first four acts of the play. ${ }^{22}$ Lorenzo's explanation may be pedantic, but it is the opposite of a critique. When Jessica says she is never merry when she hears sweet music, he responds that this is because her spirits are "attentive," or receptive to music, which can stun and gentle even the wildest of animals (5.1.69-78). If Lorenzo is thinking of Shylock when he subsequently declares that "the man who hath no music in himself / . . / Is fit for treasons, stratagems, and spoils," then he is distinguishing Jessica from her father on the basis of her responsiveness to music (5.1.82-84). Far from criticizing her lack of merriment, Lorenzo reassures Jessica that hers is the appropriate response to "sweet music."

As Portia and Nerissa enter, the musicians whom Lorenzo summoned earlier apparently continue playing, for the women remark on their music several lines later (5.1.96-97). But first Portia draws the audience's atten-

21. "Exultet iam angelica turba caelorum: exultent divina mysteria: et pro tanti regis victoria, tuba insonet salutaris... Laetetur et mater ecclesia, tanti luminis adornata fulgoribus: et magnis populorum vocibus haec aula resultet."

22. For this reading, see esp. Berley, "Belmont Blues," 185-204. 
tion to the candle in her house. Nerissa observes that they could not see it earlier, when the moon shone, and Portia agrees, moralizing thus:

So ... the greater glory $\operatorname{dim}[\mathrm{s}]$ the less

A substitute shines brightly as a king

Until a king be by, and then his state

Empties itself as doth an inland brook

Into the main of waters.

$$
\text { (5.1.92-96) }
$$

Given the scene's other contextual cues, the presence of this single candle may have been enough to remind the audience of the paschal candle in the darkened church at the beginning of the Easter Vigil, but Portia's commentary on its virtues also aligns surprisingly closely with the Exultet's concluding praise of that candle:

Let [this candle] mingle with the lights of heaven

And continue bravely burning

To dispel the darkness of this night!

May the Morning Star which never sets

Find this flame still burning:

Christ, that Morning Star,

Who came back from the dead,

And shed his peaceful light on all mankind.

$$
\text { (Lines 77-84) }{ }^{23}
$$

To apply Portia's words to this portion of the hymn, the paschal candle is the "substitute" that will first "empt[y] his state" into the greater light of the heavens (including the literal morning star) and then into the even greater light of Christ (the metaphorical morning star). The candle symbolizes but is not as powerful as the lights of heaven, which in turn symbolize but are not as powerful as the light of Christ, who will eventually surpass and subsume those lesser lights. The Christological reading suggested by placing Portia's words alongside the Exultet has larger resonances for a play so preoccupied with issues of succession and substitution. If Antonio in act 4 is supposed to be read as a sacrificial, Christlike figure, Portia's words remind us that he is not the thing itself, but a mere prefiguration. ${ }^{24}$ Both the hymn and the scene

23. "Ut cereus iste ... ad noctis huius caliginem destruendam indeficiens perseveret. Et ... supernis luminaribus misceatur. Flammas eius lucifer matutinus inveniat. Ille, inquam, lucifer, qui nescit occasum. Ille qui, regressus ab inferis, humano generi serenus illuxit."

24. In fact, Antonio seems less like a typical Christ figure than like Isaac bound for sacrifice on Mount Moriah—an event linked in both Judaism and Christianity to the Passover. Late Second Temple and Rabbinic Judaism traditionally read Isaac not as a helpless child, but as a young man who willingly submitted himself to God's demand for sacrifice. The earliest Chris- 
in Belmont may also allude to the parable of the wise and foolish virgins trying to keep their lamps going as they wait for the arrival of the bridegroomtraditionally understood as Christ at his second coming (Matt. 25:1-13). The candle in Belmont, of course, burns in anticipation of the return of a literal bridegroom, but he, like Antonio, is only a prefiguration of the real thing. The Easter Eve setting of act 5 hallows Belmont-it is, in Portia's words, the "season" that brings the characters' actions "to their right praise and true perfection" (5.1.106-7) — but like all Easter celebrations, it both points ahead to the second coming and marks the great distance from here to there.

Although act 5 contains numerous allusions to the Easter Vigil and the language of the Exultet, even audience members relatively unfamiliar with the hymn or the service might still have picked up on some of the scene's pervasive Easter symbolism. In addition to the features I have already touched on, Portia and Nerissa are reported to be "stray[ing] about / By holy crosses" on their way back to Belmont; Lancelot and Stefano make repeated references to the expected return of their "master"; and Jessica and Lorenzo, like Jesus's disciples (or like the virgins in the parable), intend to stay awake but fall asleep in a garden $(5.1 .30-31,34,46-47,48-54,108-9)$. Lorenzo also makes two allusions to the Eucharist, which is the culmination of the conversion rite at the Easter Vigil but also a commemoration, for all Christians, of the Last Supper. Early in the scene Lorenzo describes the stars as "patens"- the standard term for eucharistic plates-"of bright gold," ${ }^{25}$ and at the end of the scene he tells Nerissa and Portia that they "drop manna in the way / Of starvèd people" (5.1.57-58, 293-94). Coming as this latter remark does after Nerissa's announcement that "the rich Jew" has given Jessica and Lorenzo "a special deed of gift, / After his death, of all he dies possessed of" (5.1.290-91), the reference to manna is hard to hear without an additional valence. Literally, Nerissa is simply saying that Jessica and Lorenzo will inherit Shylock's property. But Lorenzo's claim that this news is like manna in the wilderness - a familiar type of Christ ${ }^{26}$ - suggests we might also understand Nerissa's words as a confirmation that Lorenzo and Jessica

tians inherited this reading and assimilated it to their understanding of Jesus's sacrifice. Isaac is therefore a type of Christ. See Talley, Origins of the Liturgical Year, 49-50; Jon D. Levenson, The Death and Resurrection of the Beloved Son: The Transformation of Child Sacrifice in Judaism and Christianity (New Haven, CT: Yale University Press, 1995), 111-12, 125-42, esp. 133-34.

25. The editor of the Arden third edition of the play also highlights the way this line points to Jessica's conversion: "It is Jessica's marriage to Lorenzo that gives her access to the Christian salvation symbolized by the Eucharist. ... It also, rhetorically and poetically, performs Jessica's transformation into a Christian wife" (John Drakakis, ed., The Merchant of Venice [London: Arden Shakespeare, 2010], 108). The term "patens" is more strongly associated with the Catholic Church than the English, but it is used in the prayer book in both its 1549 and 1662 editions.

26. This relationship is established most explicitly in John 6:31-35. Jesus is challenged to give his auditors a sign like the manna that God sent the Israelites in the wilderness, whereupon he describes himself as the true bread sent down from heaven. 
are heirs not only of Shylock, but also of Jesus, another "rich Jew" whose death has left them in possession of salvation. The demise of one will answer their material needs; the other, their spiritual. Perhaps this alignment of Shylock with Jesus is only ironic, meant to highlight how worthless the riches of the former are compared with those of the latter. But in a play that has already demonstrated the fungibility of roles such as merchant and Jew, we would do well to take seriously the possibility that in act 5 it is Shylock-not Antonio, Bassanio, or Portia-who is the Christ figure. After all, like Jesus, Shylock remains irreducibly Jewish even as he is claimed by Christianity, and like Jesus, his disappearance ushers in Easter. Indeed, as with Jesus's empty tomb, Shylock's absence from act 5 might be said to be a precondition for belief in his transformation.

Regardless of how one reads the "rich Jew" line, however, the play's use of the Easter Vigil demonstrates that its attitude toward Shylock's conversion is more complicated than it may initially have seemed. The fact that the announcement of his conversion is swiftly followed by echoes of an early Christian liturgy suggests that Shylock's conversion is symbolic not only of the anticipated conversion of the Jews at the Second Coming, but also of the earliest Christians, who were simultaneously Jews. ${ }^{27}$ In other words, Shylock's conversion might not be a conversion at all, if by that we mean a radical break or reversal. Instead, it is a sign of continuity. Imagining a Jewish identity that is always already Christian (or vice versa) may be a self-serving Christian fantasy, ${ }^{28}$ but it is not the religious triumphalism expressed by many of the play's other characters, who insist, in the words of the duke of Venice, on "the difference" between the Christian and Jewish "spirit" (4.1.363). We might call it, perhaps, Supersessionism Lite.

\section{NEITHER JEW NOR GREEK}

While the language and rituals of the Easter Vigil present an uncomplicated narrative of Jewish-Christian succession, the liturgy's complicated history

27. That Christianity's separation from Judaism was gradual and prolonged is now beyond dispute. See, e.g., Daniel Boyarin, Border Lines: The Partition of Judaeo-Christianity (Philadelphia: University of Pennsylvania Press, 2004); Adam H. Becker and Annette Yoshiko Reed, eds., The Ways That Never Parted: Jews and Christians in Late Antiquity and the Early Middle Ages (Tübingen: Mohr Siebeck, 2003). Early Modern Christians surely did not know just how long or how gradual the process was, but Acts and the epistles of Paul provide ample evidence that the earliest Christians still considered themselves Jews; any attentive reader would have noticed that the apostles were not yet decided about whether gentile converts should be circumcised and follow the law of Moses. For a somewhat different take on the way Shylock aligns with early JewishChristian converts, see Lupton, Citizen-Saints, chap. 3.

28. For the many ways that Early Modern Christians identified with the ancient Israelties and imagined biblical Jews as always-already Christian, see Achsah Guibbory, Christian Identity: Jews and Israel in Seventeenth-Century England (Oxford University Press, 2010), esp. 13-20. 
raises implicit questions about that narrative and about the immutability of any religious identity. Given the liturgy's close association with the early church, Shakespeare's evocation of the service in the context of Jewish conversions could be read as a miraculous reminder of God's faithfulness to his chosen people, drawing an unbroken line from the ancient Israelites to the present hour. On the other hand, as a discarded relic from the past, the liturgy could also have been read as an emblem of rupture and discontinuity. But although the history of the service is a crucial part of its interpretative meaning, much of that history has hitherto been obscure or misunderstood. Whereas some pre-Reformation practices, such as prayers for the dead and the invocation of saints, get discussed and debated for decades, no one seems either to have challenged or applauded the elimination of the Easter Vigil. We know that the liturgy was celebrated during Henry VIII's reign (1509-47) and again during Mary's (1553-58), but it is absent from even the 1549 prayer book. In an effort to explain what might have happened to the liturgy, Eamon Duffy has speculated that the vigil was simply not a popular feature of late medieval lay piety, and the few liturgical historians who have considered the question have come to similar conclusions. ${ }^{29}$

Certainly, by the sixteenth century much of the visual poetry of the service was gone. Having been pushed back to Holy Saturday morning in order to accommodate the many confessions that priests needed to hear before Easter Sunday, the vigil lost the drama of the single candle in the darkened church and the gradual breaking of Easter dawn. It also lost some of its other associations with its origins; without the early church's steady supply of converts, baptisms were rarely celebrated. At the time of Merchant's first performance, then, the Easter Vigil would not have been officially celebrated in England for almost forty years, and no living person anywhere in Europe could have celebrated the service in the way that it is evoked in the play. This means that Shakespeare's allusions cannot be read as mere detritus from the Catholic past, much less as secret signals to the recusants in his audience. Rather, his use of the Easter Vigil asks us to look harder at the historical record for evidence of what English men and women might have known about the ceremony and how they might have read it as commenting on Shylock's conversion.

Protestant familiarity with the vigil appears to have come through multiple channels. First, and most obviously, Protestants might have known of the service from England's pre-Reformation past. At the time of Merchant's first performances, anyone over the age of fifty would have been old enough both to have experienced the service and to remember it (albeit in the

29. Eamon Duffy, The Stripping of the Altars: Traditional Religion in England, 1400-1580, 2nd ed. (New Haven, CT: Yale University Press, 2005), 29-31; Senn, People's Work, 162-65. 
diminished form described above), and a certain number of younger people might have either heard about it from their parents or have encountered the liturgy in textual form. ${ }^{30}$ Given the play's heavy reliance on the language of the Exultet, it is likely that Shakespeare's own familiarity with the Easter Vigil was at least partly textual-and Hamlet gives us another reason to believe that Shakespeare may have had access to either the pre-Reformation Sarum missal or the post-Tridentine Roman missal. ${ }^{31}$ Such texts were not exclusively familiar to recusants. After Elizabeth's accession many basically conforming Protestants continued to hold on to articles from their Catholic past, just as many parishes did-whether from nostalgia, inertia, or simply as a hedge against another national change in religion. ${ }^{32}$ There are even hints in parish records that the Easter Vigil service may have continued to be celebrated in some form in a handful of places in Elizabethan England and post-Reformation Germany, and not necessarily by those who resisted the new religion. ${ }^{33}$ The other obvious means for Protestant encounters with

30. Apart from England's return to Catholicism under Mary, evidence that the Easter Vigil service was restored and being observed even up to the eve of Elizabeth's accession comes from sources that describe the centrality of the paschal candle to London parish life. See Articles to be enquired of in the generall visitation of Edmonde Bisshoppe of London (London, 1554), Cii 1r, Early English Books Online, http://eebo.chadwyck.com/ (hereafter EEBO); A London Provisioner's Chromicle, 1550-1563, by Henry Machyn: Manuscript, Transcription, and Modernization, http://por ter.umdl.umich.edu/m/machyn/index.html (in March 1558, Machyn notes that "The twentyfirst day of March was the Paschal, for the Abbey of Westminster made there the weight of three hundred of wax. And there was the master and the wardens of the wax-chandlers, twenty more at the making").

31. The Sarum (Salisbury) rite—or, more properly, "Sarum use"-was the most widespread Christian rite in pre-Reformation and Marian England and remained popular afterward. However, the post-Tridentine Roman rite soon became the standard for most of the Catholic Church and was the one followed by England's Jesuit missionary priests. Stephen Greenblatt has noted that Hamlet's "hic et ubique?" (1.5.158) might be an echo of the Sarum liturgy for the dead (in fact this portion of the liturgy is the same in both the Sarum and the Roman rite), and Debora Shuger has added that the phrase is a surprisingly uncommon one, appearing virtually nowhere else in classical, church, or neo-Latin texts. See Stephen Greenblatt, Hamlet in Purgatory (Princeton University Press, 2001), 16, 234-35; Shuger, personal conversation with the author, April 2012.

32. Upon Mary's succession, most churches had found themselves suddenly needing to reacquire, often at great expense, items that had been sold, destroyed, or given away only a few years earlier. One need not have had any self-consciously Catholic sympathies to be uncertain which devotional practices were acceptable or forbidden—or which might be reinstated later. See, e.g., Alexandra Walsham, Church Papists: Catholicism, Conformity, and Confessional Polemic in Early Modern England (Suffolk: Boydell, 1993), 14-21; Duffy, Stripping of the Altars, 570-93; Patrick Collinson, "William Shakespeare's Religious Inheritance and Environment," in Elizabethans (New York: Hambledon \& London, 2003), 222-27, 231-32.

33. Research undertaken by the Oxford Movement into the ceremonies of the postReformation church quotes an entry from the account books for St. Mary's parish in Shrewsbury which shows payments for wax for the paschal candle during Elizabeth's reign (no specific year is noted). Since there is no rite involving a paschal candle in the sixteenth-century prayer 
the Easter Vigil are travel to Catholic countries or the narratives of those who had. Anthony Munday's English Romaine Life (1582), for example, includes a detailed description of a vigil he witnessed at Rome, which even featured the baptism of adult Jewish converts. ${ }^{34}$

But although the liturgy's medieval past and its Catholic present were surely important to its continuing familiarity, surprisingly few works discuss the Easter Vigil in those contexts (or associate the liturgy with "popery" or superstition). ${ }^{35}$ Instead, most of the works I have found discuss the Easter Vigil as celebrated within the early church. They also indicate widespread familiarity with two of the elements most pertinent to Shakespeare's evocation of the service in Merchant: the Exultet and the ancient practice of Eastertide baptisms. Although I cannot find the Exultet printed in full in any work published in the British Isles after Mary's death, lines from the hymn crop up in numerous works. This should not be surprising. The hymn, which dates back to the fourth century, was frequently assigned to the authorship of Augustine, Ambrose, or Gregory the Great, and its theology has an equally venerable pedigree. ${ }^{36}$ Perhaps for these reasons, when Protestants quote the

book-all ceremonial candles were seen as "popish"- this strongly suggests the continuing celebration of the Easter Vigil service at least at this one parish, and at least for a short while into Elizabeth's reign. See Hierurgia Anglicana; or, Documents and Extracts Illustrative of the Ritual of the Church of England after the Reformation (London, 1848), 346. Ron Bagnall, a Lutheran liturgist, has also found evidence that Lutherans in Dessau in the 1540s continued to celebrate a form of the Easter Vigil liturgy that involved the singing of the Exultet. See Ron Bagnall, "Liturgia Augustana: The Paschal Vigil," Lutheran Forum 24 (1990): 25-26.

34. Munday's description of the conversion of Jews during the Easter Vigil service highlights many of the same features as the allusion in Shakespeare's play, including the paschal candle (which in his account the converts are brought to after their baptism: "they be brought into the Church, and there they see the hallowing of the Paschall, which is a mighty great wax Taper"). Despite Shakespeare's known associations with Munday, to my knowledge no one has noted the similarities between Merchant and this passage from Munday. See English Romaine Life (London, 1582), 32-33 (EEBO).

35. I have found one wholly negative account by a Marian exile, who translates the Easter Vigil service into English with the stated purpose of showing the English exactly how offensive they should find their participation in it; three other works single out for negative attention certain rites within the vigil, specifically the blessing of fire, the paschal candle, and holy water. See Nicholas Dorcastor, The Doctrine of the Masse Booke (Wyttonburg [London?], 1554), Biiii 4v-7r, Ciii-Ciiii 3r; Thomas Naogeorg, The Popish Kingdom, trans. Barnabe Googe (London, 1570), 52; Philips van Marnix van St. Aldegonde, Bee Hive of the Romish Church, trans. George Gylpen (London, 1579), 128v and 223r; Thomas Becon, Reliques of Rome (London, 1563), 166r-67r (all via EEBO). Despite his dislike of the rites of hallowing, Becon still expends several sentences on the debate over the authorship of the Exultet and elsewhere speaks approvingly of the primitive church's custom of limiting baptisms to Easter and Pentecost (166r, 95).

36. The ascription of the Exultet to Augustine rests partly on Augustine's own claim to have written a hymn in praise of candles and partly on the great antiquity of an Easter Vigil liturgy involving the blessing of the paschal candle. A number of different blessings with similar tropes and forms once existed, and the Exultet itself appears to be a composite text, with parts dating 
Exultet, they seem to expect their readers to know it. Several writers quote lines with no attribution at all, ${ }^{37}$ while others identify the source in a minimal way, as "benedictione cerei" (blessing of candles) or "Gregory" or "Ambrose." 38 Most significantly, two works by prominent churchmen, Bishops John Jewel and Joseph Hall, each use the text of the Exultet as evidence against Catholic controversialists, quoting passages from the hymn to prove the antiquity of Protestant doctrines about the Eucharist and salvation, respectively. ${ }^{39}$ In other words, these two ecclesiastics in the Church of England treat the hymn as an authentically Christian document rather than one tainted by association with Catholicism. But if the Exultet appears to have been a relatively familiar feature of the Easter Vigil, baptism is unquestionably the most well-known aspect of the service. References to the early church's custom of Eastertide baptisms appear regularly in early modern sermons, ${ }^{40}$ and the tradition is also mentioned in the Elizabethan prayer book in the heading to the rite of baptism. ${ }^{41}$

In the popular imagination, then, the Easter Vigil seems to have been far more closely linked to the early church than to the Catholic Church. This is

from the fourth century and parts as late as $600 \mathrm{CE}$. The Exultet did not become the standard blessing until the ninth century. See Kelly, Exultet in Southern Italy, 31-53.

37. One interesting example comes from a contestant in the "querelle des femmes," who takes the four lines that describe the "necessary fault of Adam" and claims that it is actually Eve whose actions are redeemed by the verse. D. T. [Daniel Tuvell], Asylum Veneris; or, A sanctuary for ladies (London, 1616), 9. For other texts that quote the Exultet without attribution, see Godfrey Goodman, The Fall of Man (London, 1616), 435, and Christopher Hampton, Threefold State of Man upon Earth (Dublin, 1620), 61 (all via EEBO).

38. John Jewel, Replie Unto M. Hardings Answeare (London, 1565), 337; Joseph Hall, The Olde Religion (London, 1628), 46, marginal note; George Downame, A Treatise of Justification (London, 1633), 551 (all via EEBO). All three authors identify their quotations as being from the Easter Vigil service, though only Jewel gives a detailed citation ("they were wonte to singe at the blissinge of the Paschal Taper, Haec sunt festa Paschalia, in quibus verè Agnus occiditur. This is the Paschal Feaste, wherein verily, and indeede the Lambe is slaine"). Both Hall and Downame identify their quotation as being from the "benedictione cerei."

39. Jewel quotes the "this is our paschal feast" portion of the Exultet (see previous note) to argue that "verily" does not mean Christ's body and blood are literally present in the Eucharist (Jewel, Replie, 337), while Hall argues that the Catholic Church misunderstands the way the ancients used the word "merit," and uses the "O felix culpa" portion of the Exultet as proof that redemption is not something human beings earned (Hall, Olde Religion, 46). Downame makes a point similar to Hall's.

40. For a few of the many references to Eastertide baptisms, see, e.g., David Chytraeus, $A$ postil or orderly disposing of certeine epistles usually red in the Church of God, trans. Arthur Golding (London, 1570), 98-99; Henoch Clapham, Theological Axioms (London, 1597), esp. Biii 1v; Lancelot Andrewes, "A Sermon Preached before the King's Majestie at White-Hall, on the V. of Aprill, A. D. MDCXVIII, being Easter Day," in XCVI Sermons (London, 1629), 529-30 (all via EEBO); John Donne, Complete Sermons, ed. George R. Potter and Evelyn Simpson, 10 vols. (Berkeley: University of California, 1953-62), 5:162, 222.

41. See the 1559 prayer book, http://justus.anglican.org/resources/bcp/1559/Baptism _1559.htm. 
equally true of Shakespeare's use of the allusion, for Merchant goes out of its way to focus on the less controversial aspects of the service. The play omits, for example, any reference to the blessing of new fire or of holy water, rites that Protestants almost universally condemned for their pagan overtones, and even the play's evocation of the paschal candle transforms that candle into a simple source of illumination far off in Portia's household; it is not blessed, as in Catholic worship, nor does it have any sacramental force. ${ }^{42}$ Although Portia moralizes upon the candle using Christological language that echoes the Exultet, in the play the candle is merely a metaphor or a symbol rather than a sacred object itself. Some members of Shakespeare's original audience might still have reacted negatively to the allusions as a result of the liturgy's Catholic associations, but the play works to diminish that likelihood by focusing on things that Catholics and Protestants could broadly agree on. ${ }^{43}$

Shylock's conversion is one of those things. For although Heather Hirschfeld and Jeffrey Shoulson have noted that Jewish conversions were often read in the context of Protestant-Catholic disputes, the kind of Jewish conversion evoked by the Easter Vigil is strictly a fantasy, based in a distant past shared by both Protestants and Catholics. ${ }^{44}$ It is not merely that, in the face of Jewish difference, intra-Christian differences look comparatively minor, though that is certainly true. Rather, the period evoked by the Easter Vigil is one where the line between Jew and Christian was relatively thin; the erasure of Jewish difference therefore becomes an erasure of Christian difference. Just as the Exultet's "this is the night" collapses the Exodus, the crucifixion, and the present liturgy into one single moment, so does Shakespeare's evocation of the Easter Vigil collapse Christian history into a Christian eternity that exists outside of time and denominational division, simultaneously conjuring up the early church, the medieval church, and even-through his elimination of the liturgy's more "popish" elements—a prospectively reunified and purified Christianity. Shylock and Jessica's conversions, then,

42. Indeed, whether early modern Protestants knew as much, these rites were not original to the service; the liturgical historian Theodor Klauser notes that they were added by the Franco-German church in the eighth or ninth centuries. See Theodor Klauser, A Short History of the Western Liturgy: An Account and Some Reflections, trans. John Halliburton (London: Oxford University Press, 1969), 81-82.

43. Jeffrey Knapp argues persuasively for just this kind of broad-based, inclusive Christianity on the part of both Shakespeare and the Renaissance stage more generally in Shakespeare's Tribe: Church, Nation, and Theatre in Renaissance England (University of Chicago Press, 2002).

44. See Heather Anne Hirschfeld, "We All Expect a Gentle Answer, Jew': The Merchant of Venice and the Psychotheology of Conversion," ELH 73 (2006): 61-81; Jeffrey Shoulson, Fictions of Conversion: Jews, Christians, and Cultures of Change in Early Modern Europe (Philadelphia: University of Pennsylvania Press, 2013), esp. 28-39. 
become part of the same collapsing of time and religious identity, at once gesturing backward to the moment before Christianity was Christianity and forward to a day when Catholic and Protestant, Jew and gentile are once more the same. The fact that even Shylock is briefly aligned with Christ could be read as the play's most radical denial of religious difference.

Of course, such a denial is not sustainable in the real world of late sixteenth-century England, and neither is such an ahistorical understanding of a service so closely linked to two discrete moments in Christian history. Indeed, the Easter Vigil's ambiguous status in Protestant England means that the play's use of it potentially undermines the supersessionist argument expressed in the liturgy itself: Christian history is not, as it turns out, a narrative of continuity where the roots of today's faith are easily discernable in the past. Even if the play's evocation of the Easter Vigil conjured up only associations with the early church and even if Protestants had wholly positive feelings about that part of their past, the allusion could not help but signal the impermanence of religious practice. Centuries earlier the vigil lost its baptism of converts and its nighttime setting; forty years earlier, England lost the service entirely. However inadvertently, the liturgy demonstrates that Christian history is a history of change.

Shakespeare's allusions to the Easter Vigil therefore suggest three different ways of reading the play's attitude toward Shylock's conversion. The first is simply supersessionist. In this interpretation, the allusions I have traced add more evidence to the case that Lewalski and others made decades ago. This is a plausible reading, though one that does not do full justice to the complexities of either the Easter Vigil or Shakespeare's play. A second interpretation, for which I have been arguing in most of this essay, sees Merchant's use of the liturgy as reflecting a generally supersessionist theology in the service of a broadly inclusive vision. Shakespeare's allusions to a wellknown practice from the earliest days of Christianity serve to unite his audience in a common identity based on their shared past as both Christians and Jews. The play is unquestionably more interested in Christian harmony than in Christian-Jewish harmony, but it includes the Jews (at least notionally and rhetorically) in its vision of a world without religious difference. Given the festive energies of act 5, I read the allusion as an ecumenical celebration of Easter that dissolves Jewish difference and the disruptive forces of Shylock's grief and hatred. This reading does not ask us to ignore the hypocrisy or the selfishness of the play's Christian characters and neither does it deny the humanity and generosity in Shakespeare's depiction of Shylock, but it recognizes the limits of that generosity in Renaissance Europe. An early modern Christian may well have found Antonio's treatment of Shylock abominable, and perhaps even have interpreted Shylock's vengefulness as the result of years of mistreatment and marginalization, but he would still have assumed the nonnegotiable truth of Christianity. For an 
early modern Christian, feeling Shylock's pain is perfectly compatible with rejoicing at his conversion.

That said, I believe it is possible to read the play's use of the Easter Vigil in a third way, one that views the celebration of Shylock's conversion more skeptically, and undermines the happy endings set forth in my first two interpretations. The play, in my estimation, does not foreground an ironic reading, but it does not foreclose one, either. In this interpretation, Jewish conversions cannot provide evidence of Christianity's claim to an unbroken chain of succession from Abraham, because the Easter Vigil shows even Christian history to be discontinuous and unstable. Darker readings of the play require ignoring much of the comedy of act 5 and treating the play's happy ending far more suspiciously than we treat the endings of plays that do not implicate Shakespeare in prejudices from which we would rather exempt him. Nevertheless, there are good reasons not to want to stage a play that presents a forced conversion as a cause for celebration, and familiarity with the liturgy's complicated history permits us to see the play as resisting some of its own liturgical and theological premises. Yet whether we understand Merchant as celebrating Shylock's conversion or not, the echoes of the ancient Easter service ensure that he is a palpable presence until play's end. 